Conference paper (Original scientific paper)

UDC: $334.722: 330.35: 004$

https://doi.org/10.18045/zbefri.2019.2.653

\title{
Does digitalization affect the contribution of entrepreneurship to economic growth?*
}

\author{
Maja Ivanović-Đukić1, Tatjana Stevanovic ${ }^{2}$, Tamara Rađenovic ${ }^{3}$
}

\begin{abstract}
The paper analyses the contribution of different types of innovative entrepreneurship: new products entrepreneurship (NP), new technology development entrepreneurship (NT), high growth expectation entrepreneurship (HG), and average growth expectation entrepreneurship $(A G)$ to economic growth through the EU regions, which differ from each other on the degree of digitization. The regions were created by the application of cluster analysis. The clustering criterion was the level of digitization measured by the Digital Economy and Society Index. Hierarchical regression models were developed with purpose to investigate the effect of different types of innovative entrepreneurship on economic growth, on panel data for the period 2010-2017. The obtained results confirm differences in contribution of the certain types of entrepreneurship to economic growth in the EU regions, as well as, the influence of digitization on the relationship between entrepreneurship and economic growth. High growth expectation entrepreneurship and new technology development entrepreneurship have greatest contribution to economic growth in the regions characterized by a higher degree of digitization. On the other side, average growth expectation entrepreneurship and new products entrepreneurship have a dominant role in economic growth in the regions with lower levels of digitization.
\end{abstract}

Key words: digitization, innovative entrepreneurship, high growth entrepreneurship, economic growth

JEL classification: L26, M13, M40, O12, O31

\footnotetext{
* Received: 01-06-2019; accepted: 19-12-2019

1 Associate Professor, University of Niš, Faculty of Economics, Trg kralja Aleksandra Ujedinitelja 11, 18000 Niš, Serbia. Scientific affiliation: management, finance. Phone: +381 18528659. E-mail:maja.ivanovic@eknfak.ni.ac.rs.

2 Associate Professor, University of Niš, Faculty of Economics, Trg kralja Aleksandra Ujedinitelja 11, 18000 Niš, Serbia. Scientific affiliation: accounting, finance. Phone: +381 18528666. E-mail: tatjana.stevanovic@eknfak.ni.ac.rs.

${ }^{3}$ Researcher, University of Niš, Faculty of Economics, Trg kralja Aleksandra Ujedinitelja 11, 18000 Niš, Serbia. Scientific affiliation: macroeconomics, intellectual capital. Phone: +38118 528 659. E-mail: tamara.radjenovic@eknfak.ni.ac.rs.
} 


\section{Introduction}

During the last two decades, there has been the fast development of information technology, resulting in a high degree of digitization. Digitization has changed all aspects of our lives and transformed the business world. In the new business environment, an important task for policy makers is to identify the drivers of economic growth (Van Stel et al., 2005). Their identification is very important because it defines the priorities in which resources should be allocated in order to stimulate economic growth (Audretsch and Fritsch, 2002).

According to Schumpeter (1934) a key driver of economic growth is entrepreneurship, because it initiates a process of "creative destruction". Such claims are confirmed by a large number of contemporary empirical researches (Koster et al., 2011; Van Stel et al., 2018). The basic elements of creative destruction are innovations in the product, organization or process, introduced by entrepreneurs (Schumpeter, 1934). Accordingly, entrepreneurs can be seen as innovators introducing new products or innovators introducing new technologies. Also, there are differences among innovative entrepreneurs related to the expected growth rate. Some of them offer products or technologies that are new to the local or national market and expect average growth rates. The others offer innovative solutions to consumers around the world and expect high growth rates (Janjić and Rađenović, 2019). We assume that the contribution of these forms of entrepreneurship to economic growth is not the same. Therefore, our first hypothesis is:

H1: Different forms of innovative entrepreneurship do not have the same contribution to economic growth of EU countries in the digital economy.

H1a: The impact of new technology development entrepreneurship on economic growth is higher than the impact of new products entrepreneurship in the digital economy.

H1b: High growth expectation makes the largest contribution to economic growth of the EU countries in the digital economy.

Opportunities for entrepreneurs, as well as, for creative destruction, are becoming greater in the digital economy. The application of new technology enables entrepreneurs to offer new digital solutions that can change the world radically (good examples are: "Google", "Facebook", “Amazon", "Uber", etc.). Also, new sources of financing, such as crowdfunding, initial coin offering (ICO) and alike, enable entrepreneurs to transform their innovative ideas into innovative commercial solutions. But the possibilities of using digital technology are largely conditioned by the degree of digitization. Given the fact that the level of digitization in different EU regions is not the same, it can be expected that the contribution of different types of entrepreneurship can be different. Therefore, our second hypothesis is: 
H2: Digitalization affects the contribution of entrepreneurship to economic growth.

H2a: New products entrepreneurship, new technology development entrepreneurship and average growth expectation entrepreneurship have a significant contribution to economic growth in regions with lower levels of digitization.

$\mathrm{H} 2 \mathrm{~b}$ : High growth expectation entrepreneurship is the only form of entrepreneurship that has a positive influence on economic growth in highly digitized regions.

We will test these hypotheses using the hierarchical regression on the panel data for the period from 2010 to 2017. An analysis will examine the impact of the aforementioned forms of entrepreneurial activity (new products entrepreneurship, new technology development entrepreneurship, high growth expectation entrepreneurship, average growth expectation entrepreneurship) on the economic growth in the $21 \mathrm{EU}$ countries in order to identify the forms of entrepreneurial activity which have the most important role in economic growth in the conditions of digitization. We will use data from the Global Entrepreneurship Index Report.

Additionally, we will examine whether there are differences in the contribution of different forms of entrepreneurial activity to the economic growth among the regions, which differ from each other on the degree of digitization. The regions will be created by the application of cluster analysis. The clustering criterion is the level of digitization measured by the Digital Economy and Society Index. The aim of the paper is to identify forms of entrepreneurial activity which have the greatest contribution to economic growth in the certain EU regions, as well as, to propose measures that macroeconomic policy makers could implement in order to achieve maximum effects in economic growth.

The paper is structured as follows. First, it gives an overview of the literature that links different types of entrepreneurial activity with economic growth in the digital economy. The subsequent section derives the hypotheses that will be empirically tested in the paper. The next part of the paper deals with the empirical data analysis, followed by the discussion of the obtained results. The final part of the paper presents conclusions and recommendations for macroeconomic policy makers.

\section{Literature review}

An increasing level of uncertainty in the world economy since the 1970s has created more space for flexible entrepreneurial activity trying to exploit new ideas. As a result of these changes the contribution of entrepreneurship to economic growth increases (Van Stel et al., 2005), while the competitive advantage has been moved from large, established companies to small and new born businesses (Haltiwanger et al., 2013). This is confirmed by a large number of empirical studies. For 
example, a studies conducted by Carree et al. (2003; 2007), point to the fact that the economies with greater share of entrepreneurial activity in the economy compared to the ones with a smaller one have higher growth rates. The research conducted by Rusu and Dornean (2019) demonstrates that entrepreneurial activity contributes to the increasing economic productivity and national competitiveness.

The scientist have explained that, entrepreneurs may introduce important innovations by entering markets with new products or production processes, they may increase productivity by increasing competition, and enhance knowledge of what is technically viable and what consumers prefer by introducing variations of existing products and services in the market (Van Stel et al., 2005; Rusu and Dornean, 2019). The business creativity and innovations, involved in entrepreneurial activity, as well as, resulting learning process, speed up the discovery of the dominant design for product-market combinations, enable knowledge spillovers, increase productivity, and stimulate economic growth (Acs and Varga, 2005; Wong et al., 2005). The key factor leading to an increase in productivity and economic growth is recognized utilization of opportunities in such a way that it provides "new combinations" (products, markets, organization), which constitute better ways to meet existing demand (Schumpeter, 1934).

However, Baumol (1990) pointed out that entrepreneurship does not always have a positive effect on economic growth ("productive"). It can be sometimes "unproductive", and even "destructive", because some forms of entrepreneurial activities may have insignificant or even negative impact on economic growth (Baumol, 1990). Such claims are confirmed by a number of empirical studies, which proves that the different forms of entrepreneurship do not have the same contribution to economic growth (Wong, et al., 2005; Valliere and Peterson, 2009; Poschke, 2013). Previous research shows that the innovative entrepreneurship is one of the most "productive" form of entrepreneurship in contemporary dynamic environment (Salgado-Banda, 2007; Valliere and Peterson, 2009).

According to Schumpeter (1934:78), innovative entrepreneurship is the recognition and utilization of opportunities in such a way that it provides 'new combinations' (innovation): a) the introduction of a new products or of a new quality of products, b) the introduction of a new method of production which is unproven, c) the opening up of a new market, d) the provision of a new source of supply of raw materials, e) the carrying out of a new organization of industry. Innovation incessantly destroying the old structure, creating a new one (creative destruction) which creates better ways to meet existing demands (Schumpeter, 1934).

Since, innovation can be very different, there are different forms of entrepreneurship (Giones and Brem, 2017). Forms of innovative entrepreneurship can be formed based on the elements of innovation. For example, the Global Entrepreneurship and Development Institute explains and monitors two forms of innovative 
entrepreneurship: new products entrepreneurship and new technology development entrepreneurship (Acs et al., 2017). New products entrepreneurship implies product innovation. The results of this process is the supply of new or modified products/services. New product entrepreneurs are innovators who state their products or services are new to all or some customers and for which there are no or few competitors (Bosma and Kelly, 2019). The second form of innovative entrepreneurship implies process innovation. New technology development entrepreneurship is the process of new venture creation by developing novel digital technologies and/or usage of such technologies (European Commission, 2015).

Also, Global Entrepreneurship Monitor differentiates entrepreneurs based on growth (job creation) expectations. All entrepreneurs are divided into three groups: entrepreneurs with low, medium, and high growth expectations, according to the number of employees that entrepreneurs plan to hire in the next five years. Those anticipating six or more hires can be seen as medium growth-oriented entrepreneurs, entrepreneurs anticipating hire up to six are low growth-oriented, and high growthoriented are entrepreneurs who expect to employ at least 20 employees in 5 next years (Bosma and Kelly, 2019).

Previous research shows that all forms of entrepreneurial activity do not have a same impact on economic growth (Wong et al., 2005; Moreno and Casillas, 2007; Valliere and Peterson, 2009; Van Stel et al., 2018). Also, studies examining the link between different forms of innovation and economic development indicate significant differences (Howells, 2005; Bogliacino and Pianta, 2011; Pradhan et al., 2016). Accordingly, we assume that the contribution of different forms of innovative entrepreneurship to economic growth is not the same. Our first hypothesis is:

H1: Different forms of innovative entrepreneurship do not have the same contribution to economic growth of EU countries in the digital economy.

A large number of scientists have studied the contribution of entrepreneurs offering new products to economic development, given the importance of new products for improving living standards and national competitiveness. For example, Du and O'Connor (2018) investigated the influence of entrepreneurs offering new products on national level efficiency on a sample of 64 countries worldwide. Their research shows that new product entrepreneurship, significantly contribute to improving efficiency at the national level (Du and O'Connor, 2018). Also, Van Stel et al. (2011) investigated the impact of new product offering entrepreneurs on regional economic development in the Netherlands. They demonstrate that innovative entrepreneurs initiate a process of "creative destruction", which was elaborated by Schumpeter. The emergence of new innovative firms, with new products and services that compete with existing businesses, contributes to survive and grow of the most competitive companies only, thus leading to regional economic development (Van Stel and Koster, 2011). 
New technology development entrepreneurship, also, has great importance for economic growth. New technologies can revolutionize the world, and the entrepreneurs who create them make a huge contribution to economic development. For example, Henry Ford's assembly line revolutionized the automobile manufacturing industry. Also, Netflix has overthrown disc rental and traditional media industries - now known as the "Netflix effect" and being "Netflixed". A study conducted by Cenamor et al. (2019) discovers that entrepreneurs offering new technologies improve their performance and national competitiveness. Entrepreneurs and workers in new technologies will inevitably create disequilibrium and highlight new profit opportunities. Producers and workers committed to the older technology will be left stranded. It creates the process of industrial mutation, which continuously revolutionizes the economic structure, incessantly destroying the old one and creating a new one (Schumpeter, 1934). With this in mind, the authors allude to the causal relationship of entrepreneurship and economic development (Gontareva et al., 2018).

It can be expected that both groups of innovative entrepreneurship have a positive impact on economic growth, but the question is whether this impact is the same. Given the fact that new technology can lead to much deeper changes in society and the economy, it can be expected that the contribution of entrepreneurs offering new technology to economic growth is greater than the contribution of innovative entrepreneurs offering new products. Hence, our next hypothesis is:

H1a: The impact of new technology development entrepreneurship on economic growth is higher than the impact of new products entrepreneurship in the digital economy.

Further, there are differences among innovative entrepreneurs related to the expected growth rate. Some of them offer products or technologies that are new to the local or national market. The entry of such new firms into the market stimulates existing firms to do business better (Van Stel et al., 2018). Also, they have a very significant impact on economic growth, by improving the dissemination of knowledge (Wong et al., 2005), by introducing innovations on the national market and improving national competitiveness, by increasing the level of digitization (Congregado et al., 2014), etc. But, they are primarily oriented on the national market, which is limited, and they can expect average growth rates.

On the other hand, high growth oriented entrepreneurs, designed to search for repeatable and scalable business models - "start-up", have extremely important roles in economic growth, in the digital economy (Steve and Dorf, 2014). Some of them, such as "Google", "Facebook", "YouTube", etc., have caused radical changes in people's lifestyle and business activities, by offering new solutions to the problems of all people on the planet. The enormous global market allows to these entrepreneurs the extremely high income and growth rates in a very short time (Ries, 2011). At the same time, they employ a huge number of new workers 
and create enormous value added. For example, the market value of "Google" was $\$ 23$ billion in 2004, when it went public, and it employed 3,021 workers. The sixyear old company, founded by two young entrepreneurs (Larry Page and Sergey Brin) was already generating annualized revenue of $\$ 2.7$ billion and profits of \$286 million (Ritter, 2014). One of the largest and most anticipated IPOs in history had Facebook. Its market capitalization was over $\$ 104$ billion in 2012, eight years after its establishment (Walton, 2018). Also, the development of high growth oriented entrepreneurs is very often followed by the development of new industries and supportive mechanisms, such as venture capital funds, accelerators, block chain technologies, which stimulate high economic growth. Creating a new combination of resources, with the application of the digital technology, in the direction of creating economic activities that exploit the opportunities of the entire global market and achieve high growth rates, becomes the key driver of economic growth in the digital economy. Thus, our next hypothesis is:

H1b: High growth expectation (HEA) makes the largest contribution to economic growth of the EU countries in digital economy.

The great influence on the relationship between entrepreneurship and economic growth has a process of digitization, which has become very expressive in recent years (ITU, 2015). For example, over 95\% of world populations live in areas with mobile phone coverage, and $84 \%$ of them have mobile-broadband network coverage (ITU, 2016). Also, the economic distribution of the Internet is estimated at 4.2 trillion US dollars (ITU, 2015). The rapid proliferation of digital technologies and use of Internet, has profoundly changed competitive environments in the EU in recent years (Bharadwaj et al., 2013). Milošević et al. (2018) have made a comparative analysis of countries in Europe, providing information on the current position of each of the 28 countries in the EU in terms of digital economy. The authors also point to the steps they need to take to improve and boost their position in the field of digitization. The significance of digitization is also monitored through its impact on the main components of sustainable development: economic, social and environmental. In this regard, Jovanović et al. (2018) explore the correlations of DESI and other composite indexes that measure the sustainability components.

The expansive development of digitization has a significant impact on the structure of economic activity and the key drivers of economic growth (Bharadwaj et al., 2013). For example, though commerce was formerly dominated by the conventional flow of goods, services and finances, now the flow of data and information, entailed by the digitization of the economy and the creation of new digital platforms, is acquiring greater weight. Besides, while large enterprises and multinational companies have previously been the key players in the international market, and the most important drivers of economic growth, nowadays entrepreneurs and individuals have the tools and platforms to make themselves visible and gain access to the global market (Manyika et al., 2016). 
The development of digital technology, the dissemination and exchange of knowledge and information through digital platforms, and digital networks enable entrepreneurs much more to participate in the application of innovations (Lampel et al., 2011). Digital platforms, such as open source communities, or innovation competition websites, can serve as marketplaces of knowledge and innovations for entrepreneurs, or as brokers between solution seekers and problem solvers (Dushnitsky and Klueter, 2011). It makes it easier for entrepreneurs to find ideas for new products or services or to translate ideas into the prototypes (Fischer and Reuber, 2014). Also, new sources of financing, available to the entrepreneurs (such as: crowdfunding, venture capital funds, ICO, etc.), make it possible and easier for entrepreneurs to transform their innovative ideas into innovative products/services (Desirée, 2016). Besides, the use of digital platforms and network capability improve performance of entrepreneurs and SMEs (Cenamor et al., 2019) and competitiveness (Gontareva et al., 2018). For example, Kotnik and Hagsten (2018) have proven, on the sample on $11 \mathrm{EU}$ countries, that different usage of ICT by SMEs and entrepreneurs improves their competitiveness and increases exports.

The higher level of digitization directly contributes to the development of entrepreneurship and indirectly to economic growth (Acs et al., 2017). The level of economic development, the characteristics of national infrastructures, the education system, and a number of other factors, affect the different level of digitization in some countries and regions in the EU. These differences also greatly affect the form of entrepreneurial activity which is dominant in some countries and regions, as well as contribution of entrepreneurship to economic growth. Therefore, our second hypothesis is:

H2: Digitalization affect the contribution of entrepreneurship to economic growth.

Differences in the level of digitization between regions influence the possible forms of innovative entrepreneurial activity in them. There are a number of problems in the implementation of innovative digital solutions in the low-digit regions. Underdeveloped technological infrastructure, lack of digital skills and/or vision, etc., regulatory barriers, limit the use of digital technologies to their fullest potential. For these reasons, their use is often reduced to the adoption of existing technologies or incremental improvements in product/services existing on global market. Innovative entrepreneurs can transfer knowledge and ideas collected through digital networks, and offer products or technologies which are new for national markets (beside, sometimes they are not innovative in terms of technological and business knowledge that exists in developed economies). They may have very significant role for economic growth because they offer new attractive digital products/services to consumers, facilitate the use of digital technology in business for other entrepreneurs, and give ideas to potential entrepreneurs for offering similar digital solution (Markus and Loebbecke, 2013). For example, Kostoska and Hristoski (2017) determine the impact of ICTs and new product innovation 
on competitiveness of the countries of the Western Balkans: Albania, Macedonia, Montenegro and Serbia. Also, Rivza et al. (2019) have conducted a survey on the use of the digital environment to improve existing products and offer new ones, and have proved that both of them have a positive impact on national competitiveness.

Previous research shows that increasing economic growth and national competitiveness in less-developed countries can be achieved by offering new products which are not innovative in terms of global markets, adopting existing technologies or making incremental improvements in other areas (Valliere and Peterson, 2009). Study conducted by Szabo and Herman (2012) proves that EU countries with lower levels of economic growth are also characterized by lower levels of digitization. It can be expected that all forms of innovative entrepreneurship, which do not require a high level of technological infrastructure, will have a positive impact on economic growth in less-digitized countries and regions. Thus, our hypothesis is:

H2a: New products entrepreneurship, new technology development entrepreneurship and average growth expectation entrepreneurship have a significant contribution to economic growth in regions with lower levels of digitization.

On the other hand, adoption of existing technologies or making incremental improvements in product or services is no sufficient for increasing productivity and economic growth in the countries/regions that have reached high economic growth as well as high level of digitization (Szabo and Herman, 2012). In the highly digitized world, technological innovation is one of the most important determinants of productivity and economic growth (Krammer, 2015). A large firm's innovation ability, industry networks, the availability of innovation-friendly environments, the presence of intellectual property rights, the nature of state support and global economic systems, the presence of research and development (R\&D) and strategic alliances provide opportunities for entrepreneurs to create novel digital technologies and new technological solutions to consumer problems around the world. They can create the jobs and growth opportunities, by a high intensity utilization of novel digital technologies to improve business operations, invent new business models, sharpen business intelligence, and engage with customers and stakeholders and contribute to economic growth. Only entrepreneurs who can design and develop cutting-edge products and processes may contribute to economic growth (Zhao et al., 2015). It can be expected that only high-growth entrepreneurs have significant contribution to economic growth. Hence, our hypothesis is:

$\mathrm{H} 2 \mathrm{~b}$ : High growth expectation entrepreneurship is the only form of entrepreneurship that has significant contribution to economic growth in highly digitized regions. 


\section{Methodology}

The study has two phases. First, panel data regression analysis was performed in order to estimate influence of different types of innovative entrepreneurship on economic growth in $21 \mathrm{EU}$ countries. Furthermore, cluster analysis was used in order to divide all countries into homogeneous groups. The level of digitization measured by the Digital Economy and Society Index was the clustering criterion. The sample was divided into three clusters. Regression analysis is then performed on these subsamples.

Two regression models were created in order to test the validity of the first hypotheses. We stay close to the model of Van Stel et al. (2005) and Carree et al. (2002) and choose an average annual growth rate of GDP as the dependent variable. All models control for capital and labour, and following variables are used as proxies: GDP per capita (PPP 2011 \$) (GDPpc) (an explanatory variable to limit the potential impact of reversed causality), inbound foreign direct investment per capita (FDIpc) and population (POP). Data used from World Bank Development Indicators. We used forms of innovative entrepreneurship as independent variables: new products entrepreneurship (NP), new technology development entrepreneurship (NT), high growth expectation entrepreneurship (HG), and average growth expectation entrepreneurship (AG). All of them are lagged by one year. Data used from the Global Entrepreneurship Index (Acs et al., 2017).

New products entrepreneurship (NP) was indicator for innovative entrepreneurship offering new products. It was calculated by multiplying number of entrepreneurs offering new products, as percentage of total early-stage entrepreneurial activity (TEA) and gross domestic expenditure on Research \& Development (GERD) as a percentage of GDP (percentage of TEA businesses offering products that are new to at least some of the customers $\mathrm{x}$ gross domestic expenditure on Research \& Development as a percentage of GDP) (Acs et al., 2017). Data for TEA and innovative entrepreneurship offering new products used from Global Entrepreneurship Monitor (GEM). According to GEM innovative entrepreneurship offering new products are entrepreneurs who indicate that their product or service is new to at least some customers and that few/no businesses offer the same product. Total early-stage entrepreneurial activity (TEA) is percentage of 18-64 population who are either a nascent entrepreneur or owner-manager of a new business (Bosma and Kelly, 2019).

New technology (NT) was indicator of innovative entrepreneurship using new technology. It was calculated by multiplying number of entrepreneurs offering technology, as percentage of the TEA and Innovation index (percentage of the TEA businesses using new technology $x$ Innovation index) (Acs et al., 2017). Entrepreneurs offering new technology are those who offer technology that is less than 5 years old average (including 1 year). Innovation index is a complex measure of innovation including investment in research and development (R\&D) by the 
private sector, the presence of high-quality scientific research institutions, the collaboration in research between universities and industry, and the protection of intellectual property (Global Competitiveness Index).

High growth (HG) as a proxy of high growth oriented entrepreneurship was calculated by multiplying number of high growth oriented entrepreneurs, as percentage of the TEA and Business strategy (percentage of the TEA businesses having high job expectation $\mathrm{x}$ Business strategy). High growth oriented entrepreneurs expect to employ at least 20 employees in 5 next years (Bosma and Kelly, 2019). Business strategy refers to the ability of companies to pursue distinctive strategies, which involves differentiated positioning and innovative means of production and service delivery.

Average growth (AG) was calculated by multiplying number of average growth oriented entrepreneurs, as percentage of the TEA and Technology Absorption capability (percentage of the TEA entrepreneurs with average growth orientation $\mathrm{x}$ Technology Absorption capability). Average growth oriented entrepreneurs, anticipating six or more hires in 5 next years (Bosma and Kelly, 2019). The Technology Absorption capability reflects the technology-intensity of a country's start-up activity combined with a country's capacity for firm-level technology absorption (Acs et al., 2017). The List of used variables is shown in Table 1.

Table 1: List of used variables

\begin{tabular}{|l|c|c|}
\hline \multicolumn{1}{|c|}{ Variable } & Variable Type & Model \\
\hline GDP growth rate (r) & Dependent & All \\
\hline GDP per capita (PPP 2011 \$) (GDPpc) & Control & All \\
\hline Foreign direct investment per capita (FDIpc) & Control & All \\
\hline Population (POP) & Control & All \\
\hline New products entrepreneurship (NP) & Predictor & M1 \\
\hline New technology development entrepreneurship (NT) & Predictor & M1 \\
\hline High growth expectation entrepreneurship (HG) & Predictor & M2 \\
\hline Average growth expectation entrepreneurship (AG) & Predictor & M2 \\
\hline
\end{tabular}

Source: Authors

\section{Empirical data and analysis}

Data used in this study are from the Global Entrepreneurship Index and the World Bank Development Indicators database covering the period 2010-2017. Our sample includes the $21 \mathrm{EU}$ countries ( 7 countries were excluded due to the lack of the data): Austria, Belgium, Croatia, Czech Republic, Denmark, Finland, France, Germany, 
Greece, Hungary, Ireland, Italy, Latvia, Netherlands, Poland, Portugal, Romania, Slovenia, Spain, Sweden, and United Kingdom. We have in total 168 observations in our sample.

The descriptive statistics are presented in Table 2. The average GDP growth rate in analysed countries is 1.63 percent, while Greece recorded the least GDP growth rate -9.13 percent in 2011, and the highest GDP growth rate of 25.56 percent was recorded in Ireland in 2015. The average new products in the analysed countries are 0.53 , while Romania recorded the least value of NP 0.08 in 2010-2011, and the highest value of NP (1) was recorded in France and Italy in 2014 and Denmark 2014-2017. The average value of new technologies is 0.51 and the minimum value of 0 is recorded in Romania in 2010-2011, while the maximum is 1 in Sweden in 2010-2011, 2016-2017. The minimum value of average growth expectation entrepreneurs of 0.05 is recorded in Romania in 2012, while the maximum is 1 in France and Slovenia in 2014, Denmark 2016-2017 and Sweden 2015-2017. The minimum value of high growth of 0.05 is recorded in Greece in 2012, while the maximum is 1 in Ireland in 2014 and Latvia in 2014-2016.

Table 2: Descriptive Statistics

\begin{tabular}{|l|c|c|c|c|}
\hline \multicolumn{1}{|c|}{ Variable } & Minimum & Maximum & Mean & Std. Dev. \\
\hline R & -9.13 & 25.56 & 1.63 & 3.02 \\
\hline GDPpc & $17,553.28$ & $67,335.29$ & $34,346.02$ & $9,901.04$ \\
\hline FDIpc & $-3,427.90$ & $50,054.90$ & $1,968.78$ & $5,502.86$ \\
\hline POP & $1,940,740$ & $82,695,000$ & $23,269,606.82$ & $24,491,657.34$ \\
\hline NP & 0.08 & 1 & 0.53 & 0.24 \\
\hline NT & 0 & 1 & 0.51 & 0.26 \\
\hline AG & 0.05 & 1 & 0.59 & 0.24 \\
\hline HG & 0.05 & 1 & 0.45 & 0.21 \\
\hline
\end{tabular}

Source: Authors' calculations

Correlation results are presented in Table 3. 
Maja Ivanović-Đukić, Tatjana Stevanović, Tamara Rađenović • Does digitalization affect...

Table 3: Correlations

\begin{tabular}{|l|c|c|c|c|c|c|c|c|}
\hline & $\mathrm{r}$ & GDPpc & FDIpc & POP & NP & NT & AG & HG \\
\hline $\mathrm{r}$ & 1 & & & & & & & \\
\hline GDPpc & $0.2705^{*}$ & 1 & & & & & & \\
\hline FDIpc & $0.5112^{*}$ & $0.4458^{*}$ & 1 & & & & & \\
\hline POP & -0.0352 & 0.1293 & -0.1248 & 1 & & & & \\
\hline NP & $0.2433^{*}$ & $0.6613^{*}$ & 0.0924 & 0.1027 & 1 & & & \\
\hline NT & $0.3316^{*}$ & $0.4578^{*}$ & 0.1038 & 0.1158 & $0.5907^{*}$ & 1 & & \\
\hline AG & $0.3278^{*}$ & $0.5946^{*}$ & $0.1946^{* *}$ & 0.0838 & $0.6189^{*}$ & $0.6521^{*}$ & 1 & \\
\hline HG & $0.4853^{*}$ & 0.0894 & $0.1780^{*}$ & -0.0600 & $0.3557^{*}$ & $0.3116^{*}$ & $0.3779 *$ & 1 \\
\hline
\end{tabular}

Note: * Correlation is significant at the 0.01 level (2-tailed), ** Correlation is significant at the 0.05 level (2-tailed).

Source: Authors' calculations

Results show that correlation between GDP growth rate and all analysed forms of entrepreneurship (innovative - NP and NT, average and high growth - HG) is moderate and statistically significant. The strongest correlation is between the GDP growth rate and high growth entrepreneurship (0.4853).

Since we have a panel data, diagnostic checking is performed to determine the appropriate model first: pooled regression model (Pooled), fixed effect model (FEM) or random effect model (REM). The diagnostic tests are presented in Table 4. Based on the obtained results it is determined that FEM is appropriate for fitting analysed data.

Table 4: Diagnostic tests

\begin{tabular}{|c|c|c|c|}
\hline \multirow{2}{*}{ Model } & F-test & Breusch-Pagan LM & Hausman \\
\cline { 2 - 4 } & $H_{0}:$ Pooled, $H_{1}:$ FEM & $H_{0}:$ Pooled, $H_{1}:$ REM & $H_{0}:$ REM, $H_{1}:$ FEM \\
\hline \multirow{2}{*}{ Model 1 } & 6.06 & 38.52 & 19.82 \\
& $(0.0000)$ & $(0.0000)$ & $(0.0000)$ \\
\hline \multirow{2}{*}{ Model 2 } & 6.53 & 51.71 & 15.69 \\
& $(0.0000)$ & $(0.0000)$ & $(0.0013)$ \\
\hline \multirow{2}{*}{ Model 3 } & 3.14 & 6.58 & 13.98 \\
& $(0.0001)$ & $(0.0051)$ & $(0.0009)$ \\
\hline
\end{tabular}

Note: $\mathrm{p}$ values are given in ()

Source: Authors' calculations

The regression results are presented in Table 5. 
Table 5: Regression results

\begin{tabular}{|c|c|c|}
\hline & Model 1 & Model 2 \\
\hline Constant & $\begin{array}{c}14.8481 \\
{[1.36]} \\
(0.175)\end{array}$ & $\begin{array}{l}7.7293 \\
{[0.71]} \\
(0.480)\end{array}$ \\
\hline GDPpc & $\begin{array}{l}0.0002 \\
{[2.18]} \\
(0.031) \\
\end{array}$ & $\begin{array}{l}0.0002 \\
{[2.33]} \\
(0.021) \\
\end{array}$ \\
\hline FDIpc & $\begin{array}{l}0.0003 \\
{[7.57]} \\
(0.000)\end{array}$ & $\begin{array}{l}0.0003 \\
{[7.18]} \\
(0.000)\end{array}$ \\
\hline POP & $\begin{array}{c}-9.90 \mathrm{e}-07 \\
{[-2.14]} \\
(0.035) \\
\end{array}$ & $\begin{array}{c}-7.05 \mathrm{e}-07 \\
{[-1.52]} \\
(0.132) \\
\end{array}$ \\
\hline LNP & $\begin{array}{l}4.1663 \\
{[3.86]} \\
(0.000)\end{array}$ & \\
\hline LNT & $\begin{array}{l}1.4659 \\
{[1.77]} \\
(0.079)\end{array}$ & \\
\hline LAG & & $\begin{array}{l}2.5658 \\
{[2.29]} \\
(0.024)\end{array}$ \\
\hline LHG & & $\begin{array}{l}4.3627 \\
{[3.65]} \\
(0.000)\end{array}$ \\
\hline $\mathrm{R}^{2}$ & 0.7009 & 0.6853 \\
\hline Adjusted $\mathrm{R}^{2}$ & 0.6391 & 0.6203 \\
\hline F statistics & $\begin{array}{c}27.55 \\
(0.0000)\end{array}$ & $\begin{array}{c}24.98 \\
(0.0000)\end{array}$ \\
\hline
\end{tabular}

Note: $t$ values are given in [ ], p values are given in ( ), L indicates one period lagged value Source: Authors' calculations

Model 1 analyses the impact of new products entrepreneurship (NP) and new technology development entrepreneurship (NT) on GDP growth rate in $21 \mathrm{EU}$ countries in the period from 2010-2017. Model 2 analyses the impact of high growth expectation entrepreneurship (HG), average growth expectation entrepreneurship (AG) on the economic growth on the same sample of countries and in the same time period. Model 1 shows that both types of innovative entrepreneurship have positive and statistically significant impact on economic growth, as we expected. But, impact of new product development is higher compared to the impact of new technology development, which is unexpected. The estimated model explains 70.09 percent 
change in GDP growth rate and this model is statistically significant as confirmed by the $\mathrm{F}$ test.

Model 2 explains the effects of average and high growth entrepreneurships on the economic growth. The contribution of both groups of entrepreneurs is positive and statistically significant. But, impact of high growth entrepreneurships is higher compared to the impact of average growth entrepreneurships. If the HG increases by one unit the GDP growth rate will increase by 4.36 percent. This impact is statistically significant at the level of 1 percent. If the AG increases by one unit the GDP growth rate will increase by 2.57 percent, ceteris paribus. The estimated model explains 68.53 percent change in GDP growth rate and this model is statistically significant as confirmed by the $\mathrm{F}$ test.

In order to investigate whether there are differences among different regions regarding digitization, cluster analysis was performed based on the DESI index data for 2018. The Digital Economy and Society Index (DESI) is a composite index that summarizes 30 relevant indicators on Europe's digital performance and tracks the evolution of the EU Member States, across five main dimensions: Connectivity, Human Capital, Use of Internet, Integration of Digital Technology, Digital Public Services (European Commission, 2018).

The cluster analysis was run on a sample of 21 countries. The squared Euclid distance measure was used for calculating the distance of the data, and Ward's method for calculating the similarity of the data. The analysis produced three clusters presented in Table 6 .

Table 6: Clusters structure

\begin{tabular}{|c|c|c|}
\hline Cluster 1 & Cluster 2 & Cluster 3 \\
\hline Austria & Croatia & Denmark \\
Belgium & Greece & Finland \\
Czech Republic & Hungary & Netherlands \\
France & Italy & \\
Germany & Latvia & \\
Ireland & Poland & \\
Slovenia & Portugal & \\
Spain & Romania & \\
UK & & \\
\hline
\end{tabular}

Source: Authors' calculations 
The characteristics and basic descriptive statistics of clusters are presented in Table 7. The third cluster shows the best digital economy performance, according to the analysed DESI dimensions. The characteristics of the second cluster are the lowest values of the analysed dimensions.

Table 7: Cluster analysis results

\begin{tabular}{|c|c|c|c|c|c|}
\hline Cluster (C) & Connectivity & $\begin{array}{c}\text { Human } \\
\text { Capital }\end{array}$ & $\begin{array}{c}\text { Use of } \\
\text { Internet }\end{array}$ & $\begin{array}{c}\text { Integration } \\
\text { of Digital } \\
\text { Technology }\end{array}$ & $\begin{array}{c}\text { Digital Public } \\
\text { Services }\end{array}$ \\
\hline $\mathrm{C} 1(\mathrm{n}=9)$ & $0.16 \pm 0.01$ & $0.15 \pm 0.015$ & $0.07 \pm 0.009$ & $0.09 \pm 0.015$ & $0.09 \pm 0.01$ \\
\hline $\mathrm{C} 2(\mathrm{n}=8)$ & $0.14 \pm 0.02$ & $0.11 \pm 0.014$ & $0.07 \pm 0.011$ & $0.06 \pm 0.014$ & $0.07 \pm 0.015$ \\
\hline C3 $(\mathrm{n}=4)$ & $0.19 \pm 0.01$ & $0.19 \pm 0.008$ & $0.10 \pm 0.006$ & $0.11 \pm 0.01$ & $0.11 \pm 0.005$ \\
\hline Total $(\mathrm{n}=21)$ & $0.16 \pm 0.02$ & $0.14 \pm 0.034$ & $0.08 \pm 0.016$ & $0.08 \pm 0.026$ & $0.09 \pm 0.018$ \\
\hline
\end{tabular}

Source: Authors' calculations

To investigate the differences among different regions regarding digitization, the regression analysis is performed on the determined clusters. Results are presented in Table 8.

The contribution of certain forms of entrepreneurial activity to economic growth is different in regions characterized by a different level of digitization. For the first cluster HG is the most important factor driving economic growth. If the HG increases by one unit the GDP growth rate will increase by 4.37 percent, ceteris paribus, this impact is statistically significant at the level of 1 percent. Also, NT has positive and statistically significant impact on economic growth on the level of 10 percent. If NT increases by one unit the GDP growth rate will increase by 2.2 percent, ceteris paribus. All other forms of entrepreneurship have a positive impact on economic growth, but this impact is not statistically significant.

For the second cluster all forms of entrepreneurship, except HG, have positive and statistically significant impact on economic growth. The average growth oriented entrepreneurs has the highest impact on economic growth (7.95), this impact is statistically significant at the level of 5 percent. Also positive and statistically significant impact on economic growth have NT and NP, but impact of NP is higher (5.79), compared to impact of NT (2.76). The impact of HG is negative and statistically insignificant. 
Maja Ivanović-Đukić, Tatjana Stevanović, Tamara Rađenović • Does digitalization affect...

Table 8: Regression results

\begin{tabular}{|c|c|c|c|c|c|c|}
\hline & \multicolumn{2}{|c|}{ Cluster 1} & \multicolumn{2}{|c|}{ Cluster 2} & \multicolumn{2}{|c|}{ Cluster 3} \\
\hline & Model 1 & Model 2 & Model 1 & Model 2 & Model 1 & Model 2 \\
\hline Constant & $\begin{array}{l}-1.0904 \\
{[-0.79]} \\
(0.434)\end{array}$ & $\begin{array}{c}-1.4199 \\
{[-0.97]} \\
(0.335)\end{array}$ & $\begin{array}{c}72.0174 \\
{[2.17]} \\
(0.035)\end{array}$ & $\begin{array}{c}39.6136 \\
{[1.34]} \\
(0.187)\end{array}$ & $\begin{array}{c}-11.7198 \\
{[-2.71]} \\
(0.013)\end{array}$ & $\begin{array}{l}-5.7554 \\
{[-0.36]} \\
(0.721)\end{array}$ \\
\hline GDPpc & $\begin{array}{l}-0.0001 \\
{[-0.47]} \\
(0.637)\end{array}$ & $\begin{array}{c}5.43 \mathrm{e}-06 \\
{[0.15]} \\
(0.879)\end{array}$ & $\begin{array}{l}-0.0004 \\
{[-1.35]} \\
(0.185)\end{array}$ & $\begin{array}{l}-0.0001 \\
{[-0.30]} \\
(0.762)\end{array}$ & $\begin{array}{l}0.0002 \\
{[2.04]} \\
(0.054)\end{array}$ & $\begin{array}{l}0.0014 \\
{[3.87]} \\
(0.001)\end{array}$ \\
\hline FDIpc & $\begin{array}{l}0.0004 \\
{[10.09]} \\
(0.000)\end{array}$ & $\begin{array}{c}0.0004 \\
{[8.36]} \\
(0.000)\end{array}$ & $\begin{array}{l}-0.0001 \\
{[-0.24]} \\
(0.809)\end{array}$ & $\begin{array}{l}-0.0001 \\
{[-0.30]} \\
(0.768)\end{array}$ & $\begin{array}{c}-0.0001 \\
{[-0.84]} \\
(0.410)\end{array}$ & $\begin{array}{l}-0.0001 \\
{[-0.15]} \\
(0.882)\end{array}$ \\
\hline POP & $\begin{array}{c}-3.21 \mathrm{e}-10 \\
{[-0.04]} \\
(0.969) \\
\end{array}$ & $\begin{array}{c}2.12 \mathrm{e}-10 \\
{[0.03]} \\
(0.980)\end{array}$ & $\begin{array}{c}-3.29 \mathrm{e}-06 \\
{[-2.20]} \\
(0.033)\end{array}$ & $\begin{array}{c}-1.98 \mathrm{e}-06 \\
{[-1.45]} \\
(0.154) \\
\end{array}$ & $\begin{array}{c}6.43 \mathrm{e}-08 \\
{[0.55]} \\
(0.587)\end{array}$ & $\begin{array}{c}-5.88 \mathrm{e}-06 \\
{[-2.07]} \\
(0.052)\end{array}$ \\
\hline LNP & $\begin{array}{l}3.009 \\
{[1.54]} \\
(0.129)\end{array}$ & & $\begin{array}{l}5.7887 \\
{[3.22]} \\
(0.002)\end{array}$ & & $\begin{array}{c}1.6782 \\
{[0.84]} \\
(0.408)\end{array}$ & \\
\hline LNT & $\begin{array}{l}2.203 \\
{[1.87]} \\
(0.067)\end{array}$ & & $\begin{array}{l}2.7622 \\
{[1.87]} \\
(0.068)\end{array}$ & & $\begin{array}{l}1.6659 \\
{[1.66]} \\
(0.111)\end{array}$ & \\
\hline LAG & & $\begin{array}{c}0.5915 \\
{[0.43]} \\
(0.671)\end{array}$ & & $\begin{array}{l}7.9535 \\
{[3.73]} \\
(0.001)\end{array}$ & & $\begin{array}{c}-2.5572 \\
{[-1.77]} \\
(0.093)\end{array}$ \\
\hline LHG & & $\begin{array}{l}4.3673 \\
{[3.17]} \\
(0.002)\end{array}$ & & $\begin{array}{l}-0.4137 \\
{[-0.15]} \\
(0.879)\end{array}$ & & $\begin{array}{c}5.4553 \\
{[2.58]} \\
(0.0018)\end{array}$ \\
\hline $\mathrm{R}^{2}$ & 0.7541 & 0.7541 & 0.6591 & 0.6747 & 0.4365 & 0.6812 \\
\hline Adjusted $\mathrm{R}^{2}$ & 0.7326 & 0.7325 & 0.5640 & 0.5840 & 0.3084 & 0.5469 \\
\hline F statistics & $\begin{array}{c}34.97 \\
(0.0000)\end{array}$ & $\begin{array}{c}34.96 \\
(0.0000)\end{array}$ & $\begin{array}{c}4.31 \\
(0.0029)\end{array}$ & $\begin{array}{c}4.93 \\
(0.0012)\end{array}$ & $\begin{array}{c}3.41 \\
(0.0198)\end{array}$ & $\begin{array}{c}6.11 \\
(0.0016)\end{array}$ \\
\hline
\end{tabular}

Note: $t$ values are given in [ ], $p$ values are given in ( ), $\mathrm{L}$ indicates one period lagged value Source: Authors' calculations

For the third cluster the high growth entrepreneurs is the only form of entrepreneurship, which has significant impact on economic growth, at the 1 percent level of significance. If the HG increases by one unit the GDP growth rate will increase by 5.45 percent, ceteris paribus. This model explains 68.12 percent change in GDP growth rate. The impact of other forms of entrepreneurship are not statistically significant. 


\section{Results and discussion}

Our paper has shown that innovative entrepreneurship contributes to economic growth in EU. This is in line with a number of previous studies (Schumpeter, 1934; Salgado-Banda, 2007; Valliere and Peterson, 2009). Our findings have confirmed that all forms of innovative entrepreneurship have positive and statistically significant impact on economic growth in $21 \mathrm{EU}$ countries, but their contribution to economic growth is not the same (our first hypothesis was confirmed).

The obtained results have shown that high growth entrepreneurship has the greatest contribution to economic growth (hypothesis H1b was confirmed). These results are similar to the previous research (Wong et al., 2005; Moreno and Casillas, 2007; Valliere and Peterson, 2009). It was unexpected that impact of new product development to economic growth was higher compared to the impact of new technology development (hypothesis H1a was not confirmed). This can be partially explained by the relatively low level of digitalization in the most analysed countries.

Additionally, our findings pointed out differences in contribution of the certain types of innovative entrepreneurship to economic growth in the EU regions characterized by different levels of digitization. This is the proof of the hypothesis that digitalization affects the contribution of entrepreneurship to economic growth. The greatest contribution to the economic growth have high growth and innovative entrepreneurship based on the application of new technologies, in regions characterized by a higher degree of digitization. On the other side, average growth oriented entrepreneurs and innovative entrepreneurship offering new products have a dominant role in economic growth in the regions with lower levels of digitization.

Results have shown that high growth expectation entrepreneurship is the only form of entrepreneurship that has positive influence on economic growth in highly digitized regions, as we assumed (hypothesis H2b). This is in line with a number of previous research (Wong et al., 2005; Valliere and Peterson, 2009; Van Stel et al., 2018). In contrast, all forms of entrepreneurship, except HG, have positive and statistically significant impact on economic growth in the least digitized regions. This is similar to the conclusions reached by Szabo and Herman (2012). Finally, HG and NT are most important forms of innovative entrepreneurship driving economic growth in the regions of moderate digitization. Generally, NP and AG are forms of entrepreneurial activity that have a significant contribution to economic growth only in low-digit regions. Their contribution to economic growth decreases with the increase in digitization, but the contribution of NT and HG then increases.

It is necessary to implement a lot of different measures in order to encourage the development of these forms of entrepreneurship in the EU and increase their contribution to economic growth. For the regions (where the countries of the 
second and third clusters belong) characterized by a higher degree of development and a higher level of digitization, the following measures can be proposed:

- To unify the digital market as much as possible, eliminate trade barriers (minimize cross-border delivery costs) among Member States, balance the VAT system and the like in all EU Member States, since many innovative HG entrepreneurs are characterised by being "born globally", or have the ability to quickly expand their business across borders.

- To provide much more sources of informal capital in the EU, since entrepreneurs do not have access to the formal capital market, and banks are not interested in them because of the high risk. In the EU there is a capital for starting a business from different regional funds, but sources of financing at the growth stage for business scaling should be provided. For example, entrepreneurs in the United States can access millions of dollars of venture capital funds, the European financial structure is not at the same level. For this reason, it is necessary to look for ways to further increase the amount of venture capital investment in start-up companies. This type of investment is key to providing start-up resources to scale the business and compete internationally (Román et al., 2013).

- To develop entrepreneurial ecosystems which will provide different forms of support (such as: mentoring, consulting services, exchange of knowledge and experience with other entrepreneurs, contacts with investors, etc.), in order to increase the number of successful fast-growing business (many entrepreneurs who have developed successful fast-growing firm are serial entrepreneurs). Creation of dynamic, open ecosystem encourages the creation and development of start-ups. The best example for this is the Silicon Valley, the most successful entrepreneurial ecosystem on the planet. There are a number of ecosystems in the EU (in London, Berlin, Stockholm, Paris, etc.) at the moment. More new ecosystems need to be created and the performance of existing ones should be improved.

- To increase the level of protection of intellectual capital because it plays an extremely important role in innovative entrepreneurship.

All of the analysed forms of entrepreneurship, excluding high growth oriented entrepreneurs have a positive and significant role in economic growth in the less digitized regions (the second cluster country). Also innovative entrepreneurship offering new products has a bigger impact on economic growth, compared to the innovative entrepreneurship offering new technologies. In these countries there are several problems that slow down the development of productive forms of entrepreneurship, such as: lack of entrepreneurial spirit, lack of capital for attracting and retaining talented entrepreneurs and financing fast-growing business, inadequate institutional support, the presence of various macroeconomic problems, corruption, unfair competition, non-incentive tax system, discriminatory legislation, 
unstable legal and political system, underdeveloped market economy mechanisms, etc. In order to increase the contribution of entrepreneurship to economic growth, it is necessary to implement different measures related to:

- The development of digital entrepreneurship,

- The development of entrepreneurial spirit,

- Solving macroeconomic problems, etc.

It is necessary to develop digital infrastructure, as well as, a competitive digital business environment in order to increase the number of digital entrepreneurs, since digital entrepreneurship is very important in these regions. In many parts of the region, access to reliable, broadband Internet infrastructures remains a major problem. It is necessary to solve this problem firstly, in order to enable all potential entrepreneurs to start the business and earn profits by doing business online. It is also important to create a dynamic and competitive digital business environment, stimulate competition, and develop highly competitive entrepreneurs in the online services industry and the development of digital applications.

Furthermore, the development of an innovative entrepreneurial culture is very important in order to further develop the innovative entrepreneurship. This must be addressed at all levels of the education system, through formal and informal courses, inspiration programs, exchange programs and training in entrepreneurship and ambitious thinking. Also, it is necessary to provide more financial stimulations for innovation, in order to encourage the next generation of innovative entrepreneurs.

The legal and regulatory infrastructure should be improved as well, particularly in the area of property rights, and government bureaucracy reduction, because this can have a stimulating effect on the development of entrepreneurial activity.

\section{Conclusions}

Entrepreneurship is very important for economic growth. The intensified digital transformation in the last two decades stimulates the development of innovative entrepreneurship and in turn contributes to the economic growth. Therefore, numerous researches have been conducted to investigate the contribution of innovative entrepreneurship to the economic growth. Nevertheless, empirical studies investigating the impact of digitalisation on the relationship between innovative entrepreneurial and economic growth are scarce. Hence, the main objective of the paper was to test whether digitalization affects the contribution of entrepreneurship to economic growth and to identify the forms of innovative entrepreneurial activity which have the greatest contribution to the economic growth in the EU regions, which differ from each other based on the degree of digitization. Panel data regression analysis was performed in order to estimate influence of four types of innovative 
entrepreneurship on economic growth in $21 \mathrm{EU}$ countries, divided into clusters created by level of digitization (measured by the Digital Economy and Society Index). Based on the obtained results the defined hypotheses are confirmed, suggesting: firstly, that innovative entrepreneurship development can significantly contribute to the economic growth in the analysed countries; secondly, all forms of innovative entrepreneurship have positive and statistically significant impact on economic growth in $21 \mathrm{EU}$ countries; thirdly, high growth entrepreneurship has the greatest contribution to economic growth in EU; fourthly, high growth and innovative entrepreneurship based on the application of new technologies have positive impact on economic growth in regions characterized by a higher degree of digitization; and finally, average growth oriented entrepreneurs and innovative entrepreneurship offering new products have a dominant role in economic growth in the regions with lower levels of digitization. The results of this study have filled the gap in the literature regarding impact of digitalisation on the relationship between innovative entrepreneurial and economic growth in EU countries, especially by taking into account the regional aspect of digital development. The identification of different entrepreneurial activities in the certain EU regions, have enabled the proposition of concrete regional policy measures that will stimulate the regional economic development in the EU. Overall, we can conclude that the increase in entrepreneurial activity generally should not be regarded as a universal solution to solve the problem of economic growth in the EU. Instead, countries should primarily focus their economic development policies on the increase of the number of high growth expectation entrepreneurs, as well as, innovative and digital entrepreneurs in the formal economy. Further research should consider focusing on the impact of some segments of digitization on development of entrepreneurship, as well as, on the factors influencing development of digital and fast growing innovative companies.

\section{References}

Ács, Z., Szerb, L., Lloyd, A. (2018) The Global Entrepreneurship Index 2018, [Internet], Available at: https://thegedi.org/wp-content/uploads/dlm_uploads/ 2017/11/GEI-2018-1.pdf, [Accessed: November 21, 2019].

Acs, Z.J., Varga, A. (2005) "Entrepreneurship, agglomeration and technological change", Small Business Economics, Vol. 24, No. 3, pp. 323-334, http://doi. org/10.1007/s11187-005-1998-4.

Audretsch, D., Fritsch, M. (2002) "Growth Regimes over Time and Space", Regional Studies, Vol. 36, pp. 113-124, http://doi.org/10.1080/00343400220121909.

Baumol, W.J. (1990) "Entrepreneurship: Productive, unproductive and destructive", Journal of Political Economy, Vol. 98, No. 5, pp. 893-921, [Internet], Available at: https://delong.typepad.com/baumol-1990-entrepreneurship.pdf, [Accessed: November 21, 2019]. 
Bharadwaj, A. et al. (2013) "Digital business strategy: Toward a next generation of insights", MIS Quarterly, Vol. 37, No. 2, pp. 471-482.

Bogliacino, F., Pianta, M. (2011) "Engines of growth. Innovation and productivity in industry groups", Structural Change and Economic Dynamics, Vol. 22, pp. 41-53, http://doi.org/10.1016/j.strueco.2010.11.002.

Bosma, N., Kelley, D. (2019) Global Entrepreneurship Monitor 2018/2019 (Report), [Internet], Available at: https://www.gemconsortium.org/report, [Accessed: November 21, 2019].

Carree, M. et al. (2007) "The relationship between economic development and business ownership revisited", Entrepreneurship and Regional Development, Vol. 19, pp. 281-291, http://doi.org/10.1080/08985620701296318.

Carree, M., et al. (2002), "Economic development and business ownership: An analysis using data of 23 OECD countries in the period 1976-1996", Small Business Economics, Vol. 19, No. 3, pp. 271-290, http://doi.org/10.1023/A:1019604426387.

Carree, M., Thurik A.R. (2003) "The impact of entrepreneurship on economic growth". In: Audretsch, D. B., Acs, Z. J. eds., Handbook of Entrepreneurship Research, Boston/Dordrecht: Kluwer Academic Publishers, pp. 437-471, http:// doi.org/10.1007/978-1-4419-1191-9_20.

Carree, M., Thurik, A.R. (1998) "Small firms and economic growth in Europe", Atlantic Economic Journal, Vol. 26, No. 2, pp. 137-146, http://doi.org/10.1007/ BF02299356.

Cenamor, J. et al. (2019) "How entrepreneurial SMEs compete through digital platforms: The roles of digital platform capability, network capability and ambidexterity", Journal of Business Research, Vol. 100, pp. 196-206, http:// doi.org/10.1016/j.jbusres.2019.03.035.

Congregado, E. et al. (2014) "The emergence of new entrepreneurs in Europe", International Economics, Vol. 138. pp. 28-48, http://doi.org/10.1016/j.inteco. 2014.01.002.

Desirée, W. (2016) "Enabling Digital Entrepreneurs", Digital Dividends, World Bank Group [Internet]. Available at: http://pubdocs.worldbank.org/ en/354261452529895321/WDR16-BP-Enabling-digial-entrepreneurs [Accessed: July 30, 2018].

Du, K., O'Connor, A. (2018) "Entrepreneurship and advancing national level economic efficiency", Small Business Economics, Vol. 50, No. 1, pp. 91-111, http://doi.org/10.1007/s11187-017-9904-4.

Dushnitsky, G., Klueter, T. (2011) "Is there an EBay for ideas? Insights from online knowledge marketplaces", European Management Review, Vol. 8, No. 1, pp. 17-32, http://doi.org/10.1111/j.1740-4762.2010.01002.x.

European Commission (2015) Digital Transformation of European Industry and Enterprises; A report of the Strategic Policy Forum on Digital Entrepreneurship, 
[Internet]. Available at: http://ec.europa.eu/DocsRoom/documents/9462/ attachments/1/translations/en/renditions/native [Accessed: July 30, 2018].

European Commission (2018) Digital Economy and Society Index, [Internet]. Available at: https://digital-agenda-data.eu/datasets/desi/indicators [Accessed: July 30, 2018].

Fischer, E., Reuber, R. A. (2014) "Online entrepreneurial communication: Mitigating uncertainty and increasing differentiation via Twitter", Journal of Business Venturing, Vol. 29, pp. 565-583, http://doi.org/10.1016/j.jbusvent. 2014.02.004.

Fritsch, M. (2007) "How does new business formation affect regional development?" Small Business Economics, Vol. 30, pp. 1-14, http://doi.org/ 10.1007/s11187-007-9057-y.

Giones, F., Brem, A. (2017) "Digital Technology Entrepreneurship: A Definition and Research Agenda", Technology Innovation Management Review, Vol. 7, No. 5, pp. 44-51, http://doi.org/https://timreview.ca/article/1076.

Gontareva, I. et al. (2018) "Features of the Entrepreneurship Development in Digital Economy", Technology in society, Vol. 7, No. 4, pp. 813-822, http://doi. org/10.18421/TEM74-19.

Haltiwanger, J., Jarmin, R. S., Miranda, J. (2013) "Who creates jobs? Small versus large versus young", Review of Economics and Statistics, Vol. 95, No. 2, pp. 347-361, http://doi.org/10.1162/REST_a_00288.

Howells C. (2005) "Innovation and regional economic development: A matter of perspective?", Research Policy, Vol. 34, No. 8, pp. 1220-1234, http://doi. org/10.1016/j.respol.2005.03.014.

International Telecommunication Union (ITU) (2015) Measuring the Information Society Report [Internet]. Available at: https://www.itu.int/en/ITU-D/Statistics/ Documents/publications/misr2015/MISR2015-w5.pdf [Accessed: august 25, 2018].

International Telecommunication Union (ITU) (2016) Measuring the Information Society Report [Internet]. Available at: https://www.itu.int/en/ITU-D/Statistics/ Documents/publications/misr2016/MISR2016-w4.pdf [Accessed: august 25, 2018].

Ivanović-Đukić, M. et al. (2018) "Contribution of Entrepreneurship to Economic Growth: A Comparative Analysis of South-East Transition and Developed European Countries", International Review of Entrepreneurship, Vol. 16, No. 2, pp. 257-276.

Janjić, I, Rađenović, T. (2019) “The Importance of Managing Innovation in Modern Enterprises", Ekonomika, Vol. 65, No. 3, pp. 45-54, http://doi.org/10.5937/ ekonomika1903045J.

Jovanović, M., Dlačić, J., Okanović, M. (2018) "Digitalization and society's sustainable development - Measures and implications", Zbornik radova 
Ekonomskog fakulteta u Rijeci: časopis za ekonomsku teoriju i praksu/ Proceedings of Rijeka Faculty of Economics: Journal of Economics and Business, Vol. 36, No. 2, pp. 905-928, http://doi.org/10.18045/zbefri.2018.2.905.

Koster, S., Rai K. (2008) "Entrepreneurship and economic development in a developing country: A case study of India", Journal of Entrepreneurship, Vol. 17, No. 2, pp. 117-137, http://doi.org/10.1177/097135570801700202.

Koster, S., Van Stel, A., Folkeringa, M. (2011) "Start-up intensity, competition and regional economic development". In ERSA conference papers, European Regional Science Association.

Kostoska, O., Hristoski, I. (2017) "ICTs and innovation for competitiveness: Evidence for Western Balkans vis-à-vis the European Union", Zbornik radova Ekonomskog fakulteta u Rijeci: časopis za ekonomsku teoriju i praksu/Proceedings of Rijeka Faculty of Economics: Journal of Economics and Business, Vol. 35, No. 2, pp. 487-518, http://doi.org/10.18045/zbefri.2017.2.487.

Kotnik, P., Hagsten, E. (2018) "ICT use as a determinant of export activity in manufacturing and service firms: Multi-country evidence", Zbornik radova Ekonomskog fakulteta u Rijeci: časopis za ekonomsku teoriju i praksu/ Proceedings of Rijeka Faculty of Economics: Journal of Economics and Business, Vol. 36, No. 1, pp. 103-128, http://doi.org/10.18045/zbefri.2018.1.103.

Krammer, M. S. (2015) "Do good institutions enhance the effect of technological spillovers on productivity? Comparative evidence from developed and transition economies", Technological Forecasting and Social Change, Vol. 94, pp. 133-154, http://doi.org/10.1016/j.techfore.2014.09.002.

Lampel, J., Jha, P. P., Bhalla, A. (2011) "Test-Driving the future: How design competitions are changing innovation", Academy of Management Perspectives. Vol. 26, No. 2, pp. 71-85, http://doi.org/10.5465/amp.2010.0068.

Manyika, A. et al., (2016) McKinsey Digital Globalization Report: The new era of global flows, [Internet], pp. 76-80. Available at: https://www.mckinsey.com [Accessed: August 25, 2018].

Markus, M., Loebbecke, C. (2013) "Commoditized Digital Processes and Business Community Platforms: New Opportunities and Challenges for Digital Business Strategies", MIS Quarterly, Vol. 37, No. 2, pp. 649-654.

Milošević, N., Dobrota, M., Barjaktarović Rakočević, S. (2018) "Digital economy in Europe: Evaluation of countries' performances", Zbornik radova Ekonomskog fakulteta u Rijeci: časopis za ekonomsku teoriju i praksu/Proceedings of Rijeka Faculty of Economics: Journal of Economics and Business, Vol. 36, No. 2, pp. 861-880, http://doi.org/10.18045/zbefri.2018.2.861.

Moreno, A.M., Casillas, J.C. (2007) "High-growth SMEs version non-high-growth SMEs: A discriminant analysis", Entrepreneurship \& Regional Development, Vol. 19, pp. 69-88. 
Poschke, M. (2013) "Entrepreneurs out of necessity: A snapshot", Applied Economics Letters, Vol. 20, No. 7, pp. 658-663, http://doi.org/10.1080/1350485 1.2012.727968.

Pradhan, R. P. et al. (2016) "Innovation, financial development and economic growth in eurozone countries", Applied Economics Letters, Vol. 23, No. 16, pp. 1141-1144, [Internet], Available at: https://repository.up.ac.za/bitstream/ handle/2263/57404/Pradhan_Innovation_2016.pdf?sequence=1, [Accessed: November 21, 2019].

Ries, E. (2011) The Lean start up: the movement that is transforming how new products are built and launched, Barnes\&Noble.

Ritter, J. (2014) Google's IPO, 10 Years Later, [Internet], Available at: https://www. forbes.com/sites/jayritter/2014/08/07/googles-ipo-10-yearslater/\#8888acb2e6ca [Accessed: August 25, 2018].

Rivza, B. et al. (2019) "Digitalization as an essential growth factor contributing in SME development (experience of Latvia and Romania)", Agronomy Research, Vol. 17, No. 1, pp. 261-270, http://doi.org/10.15159/AR.19.030.

Román, C., Congregado, E., Millán, J. M. (2013) "Start-up incentives: entrepreneurship policy or active labour market programme?", Journal of Business Venturing, Vol. 28, No. 1, pp. 151-175, http://doi.org/10.1016/j.jbusvent.2012.01.004.

Rusu, V., Dornean, A. (2019) "The Quality of Entrepreneurial Activity and Economic Competitiveness in European Union Countries: A Panel Data Approach", Administrative sciences, Vol. 9, No. 35, pp. 1-21, http://doi.org/ 10.3390/admsci9020035.

Sabela, R. et al. (2014) "Entrepreneurship and economic growth in West Bank, Palestine", Journal of Developmental Entrepreneurship, Vol. 19, No. 1, pp. 1450003-1-1450003-15, http://doi.org/10.1142/S1084946714500034.

Salango-Banda, H. (2007) "Entrepreneurship and economic growth: An empirical analysis", Journal of Developmental Entrepreneurship, Vol. 12 , No. 1, pp. 3-29, http://doi.org/10.1142/S1084946707000538.

Schumpeter, J. (1934) The Theory of Economic Development, MA: Harvard University Press.

Steve, B., Dorf, B. (2014) The Startup Owner's Manual: The Step-by-Step Guide for Building a Great Company, K\&S Ranch.

Szabo, Z., Herman, E. (2012) "Innovative Entrepreneurship for Economic Development in EU", Procedia Economics and Finance, Vol. 3, pp. 268-275, http://doi.org/10.1016/S2212-5671(12)00151-7.

Valliere, D., Peterson, R. (2009) "Entrepreneurship and economic growth: Evidence from emerging and developed countries", Entrepreneurship \& Regional Development, Vol. 21, No. 5-6, pp. 459-480, http://doi.org/10.1080/ 08985620802332723. 
Van Stel, A., Carree, M., Thurik, R. (2005) "The Effect of Entrepreneurial Activity on National Economic Growth", Small Business Economics, Vol. 24, No. 3, pp. 311-321, http://doi.org/10.1007/s11187-005-1996-6.

Van Stel, A., Concepción, R., José, M. (2018) "The relationship between start-up motive and earnings over the course of the entrepreneur's business tenure", Journal of Evolutionary Economics, Vol. 28, No. 1, pp. 101-123, http://doi. org/10.1007/s00191-017-0499-3.

Van Stel, A., Koster, S. (2011) "The relationship between start-ups, market mobility and employment growth: An empirical analysis for Dutch regions", Scales Research Reports H201104, EIM Business and Policy Research, [Internet], Available at: http://citeseerx.ist.psu.edu/viewdoc/download?doi=10.1.1.842.285 $5 \&$ rep=rep1\&type=pdf, [Accessed: November 21, 2019].

Walton, J. (2018) When did Facebook go public? [Internet], Available at: https:// www.investopedia.com/ask/answers/111015/when-did-facebook-go-public.asp, [Accessed: November 20, 2018].

Wong, P.K., Ho, Y.P. Autio, E. (2005) "Entrepreneurship, innovation and economic growth: Evidence from GEM data", Small Business Economics, Vol. 24, No. 3, pp. 335-350, http://doi.org/10.1007/s11187-005-2000-1.

Zhao, F. et al. (2015) "E-government development and the digital economy: A twoway Relationship", Internet Research: Electronic Networking, Applications and Policy, Vol. 25, No. 5, pp. 734-766, http://doi.org/10.1108/IntR-02-2014-0055. 


\title{
Utječe li digitalizacija na doprinos poduzetništva gospodarskom rastu?
}

\author{
Maja Ivanović-Đukić ${ }^{1}$, Tatjana Stevanovic ${ }^{2}$, Tamara Rađenovic ${ }^{3}$
}

\begin{abstract}
Sažetak
U radu se analiziraju različite vrste inovativnog poduzetništva kao što su poduzetništvo novih proizvoda (NP), novih tehnologija (NT), visokih očekivanja rasta $(H G)$ i prosječnih očekivanja rasta $(A G)$ te njihov doprinos gospodarskom rastu kroz regije EU-a, koje se međusobno razlikuju u stupnju digitalizacije. Regije su stvorene primjenom klaster analize. Stupanj digitalizacije mjeren Indeksom digitalne ekonomije i društva bio je glavni kriterij za grupiranje. Hijerarhijski regresijski modeli s panel podacima za razdoblje 2010-2017 primijenjeni su s ciljem da se ispita utjecaj različitih vrsta inovativnog poduzetništva na gospodarski rast. Rezultati istraživanja potvrđuju razlike $u$ doprinosu pojedinih vrsta poduzetništva gospodarskom rastu u regijama EU, kao i utjecaj digitalizacije na odnos poduzetništva $i$ gospodarskog rasta. Poduzetništvo visokog rasta $i$ poduzetništvo u razvoju novih tehnologija imaju najveći doprinos gospodarskom rastu u regijama koje karakterizira veći stupanj digitalizacije. S druge strane, prosječno očekivanje rasta poduzetništva i poduzetništvo s novim proizvodima imaju dominantnu ulogu u gospodarskom rastu u regijama s nižim razinama digitalizacije.
\end{abstract}

Ključne riječi: digitalizacija, inovativno poduzetništvo, poduzetništvo visokog rasta, gospodarski rast

JEL klasifikacija: L26, M13, M40, O12, O31

1 Docent, University of Niš, Faculty of Economics, Trg kralja Aleksandra Ujedinitelja 11, 18000 Niš. Srbija. Znanstveni interes: menadžment, financije. Tel.: +381 18528 659. E-mail: maja. ivanovic@eknfak.ni.ac.rs.

2 Docent, University of Niš, Faculty of Economics, Trg kralja Aleksandra Ujedinitelja 11, 18000 Niš. Srbija. Znanstveni interes: računovodstvo, financije. Tel.:+381 18528 666. E-mail: tatjana.stevanovic@eknfak.ni.ac.rs.

${ }^{3}$ Znanstveni istraživač, University of Niš, Faculty of Economics, Trg kralja Aleksandra Ujedinitelja 11, 18000 Niš. Srbija. Znanstveni interes: makroekonomija, intelektualni kapital. Tel.: +38118528659.E-mail: tamara.radjenovic@eknfak.ni.ac.rs. 